(c) American Dairy Science Association, 2004.

\title{
Effects of Monensin on Ruminal Forage Degradability and Total Tract Diet Digestibility in Lactating Dairy Cows During Grain-Induced Subacute Ruminal Acidosis
}

\author{
J. K. Osborne, ${ }^{1, *}$ T. Mutsvangwa, ${ }^{1, \dagger}$ O. Alzahal, ${ }^{1}$ T. F. Duffield, ${ }^{2}$ R. Bagg, ${ }^{3}$ \\ P. Dick, ${ }^{3}$ G. Vessie, ${ }^{3}$ and B. W. McBride ${ }^{1}$ \\ ${ }^{1}$ Department of Animal and Poultry Science, University of Guelph, Guelph, ON, Canada N1G 2W1 \\ ${ }^{2}$ Department of Population Medicine, University of Guelph \\ ${ }^{3}$ Elanco Animal Health, Division Eli Lilly Canada Inc., Research Park Centre, Guelph, ON, Canada N1G 4T2
}

\begin{abstract}
The effects of monensin premix supplementation on ruminal $\mathrm{pH}$ characteristics and forage degradability, and total tract diet digestibility during grain-induced subacute ruminal acidosis (SARA) in lactating dairy cows receiving a total mixed ration were investigated. Six multiparous, rumen-fistulated Holstein cows were used in a 2-treatment, 2-period (5 wk per period) crossover design. During wk 5 (d 29 to 35) of each period, SARA was induced using a grain challenge model, and ruminal $\mathrm{pH}$ was measured continuously using indwelling $\mathrm{pH}$ probes. Ruminal degradation of corn silage and alfalfa haylage was determined using the in situ (nylon bag) technique, and total tract diet digestibility was determined by total fecal collection during wk 5 . Monensin supplementation did not affect dry matter intake, milk yield, and composition, and ruminal $\mathrm{pH}$ characteristics under these experimentally induced SARA conditions. Rates of ruminal forage fiber degradability were similar between control and monensin-treated cows; however, monensin supplementation increased total tract fiber digestion. This study indicates that monensin altered total tract nutrient digestion by increasing fiber digestion at postruminal sites.

(Key words: dairy cow, monensin, ruminal acidosis, nutrient digestibility)
\end{abstract}

Abbreviation key: SARA = subacute ruminal acidosis.

\section{INTRODUCTION}

Subacute ruminal acidosis (SARA) is a common digestive disorder that affects most high-producing dairy

\footnotetext{
Received September 10, 2003.

Accepted January 7, 2004.

Corresponding author: B. W. McBride; e-mail: bmcbride@ uoguelph.ca.

*Current address: Floradale Feed Mill Ltd, Floradale, ON, Canada N0B 1 V0.

$\dagger$ Current address: Department of Animal and Poultry Science, University of Saskatchewan, Saskatoon, SK, Canada S7N 5A8.
}

herds, impairing both the health and productivity of dairy cows (Nocek, 1997). This digestive disorder is characterized by daily episodes of low ruminal $\mathrm{pH}$ between 5.2 and 5.6 (Owens et al., 1998). In early-lactating dairy cows, SARA is usually caused by the consumption of diets with high levels of rapidly fermentable carbohydrates and/or marginal, often deficient, levels of physically effective fiber (NRC, 2001). Acute acidosis, which is characterized by ruminal $\mathrm{pH}$ below 5.2 (Owens et al., 1998), is generally linked to lactic acid production, but excessive VFA production may be a more important contributor to SARA problems in many dairy herds (McGuffey et al., 2001). Potentially, ruminal acidosis can occur at any time in high-producing dairy cows, but it is most common during the transition period when cows are rapidly switched from a forage-based diet in the dry period to a concentrate-based diet in early lactation. Among its numerous manifestations, SARA impairs the activity of ruminal cellulolytic bacteria (Grant and Mertens, 1992), and various reports have demonstrated decreased fiber digestion both in vitro (Grant and Mertens, 1992, Calsamiglia et al., 2002) and in vivo (Plaizier et al., 2001, Krajcarski-Hunt et al., 2002) under SARA conditions in dairy cows.

Monensin, an ionophore, has been reported to have a variety of beneficial effects in ruminants. Reported benefits in dairy cattle include a lower incidence of ketosis and displaced abomasums, reduced loss of body condition, increased milk production and improved milk production efficiency (see review by McGuffey et al., 2001). Dennis et al. (1981) showed that monensin supplementation inhibited most lactate-producing ruminal bacteria, while most lactate-consuming ruminal bacteria were unaffected. These changes in ruminal microbial populations would be expected to result in shifts in patterns of ruminal fermentation. In beef cattle (Nagaraja et al., 1985; Burrin and Britton, 1986; Cooper and Klopfenstein, 1996) and in transition dairy cows (Green et al., 1999) consuming high-grain diets, monensin was efficacious in elevating ruminal $\mathrm{pH}$. Such increases in ruminal $\mathrm{pH}$ would make the ruminal environ- 
ment more favorable for cellulolytic bacteria which, in turn, could potentially mitigate the decrease in fiber digestibility that has been associated with SARA; however, there are no reports in the literature in which ruminal degradability and total tract digestibility of fiber has been measured under SARA conditions. Plaizier et al. (2000) showed that prepartum administration of a monensin controlled-release capsule improved apparent fiber digestibility immediately before calving and improved apparent CP digestibility immediately after calving in transition dairy cows, but these measurements were taken under "normal" feeding conditions without induction of SARA, and ruminal $\mathrm{pH}$ was not monitored. Therefore, the objective of this study was to investigate the effects of a monensin premix on ruminal forage degradability and total tract diet digestibility in lactating Holstein dairy cows during grain-induced SARA. Our hypothesis was that supplementation with monensin would minimize the impairment of fiber digestion that is common during SARA in dairy cows.

\section{MATERIALS AND METHODS}

\section{Animals and Experimental Design}

Six ruminally fistulated, multiparous Holstein dairy cows (4.0 \pm 0.5 parity, $135.8 \pm 36.7$ DIM) were used in this experiment. The study was run as a crossover design experiment with 2 treatments and 2 periods of 35 $\mathrm{d}$ each. At the beginning of the study, the cows were blocked in pairs based on DIM, and each pair was randomly assigned to receive either a monensin premix or a placebo premix. After the first 35-d experimental period, the treatments were then switched. Animals were cared for and handled in accordance with the Canadian Council on Animal Care regulations, and the University of Guelph Animal Care Committee approved their use for this experiment. The experiment was conducted at the Elora Dairy Research Center (EDRC, University of Guelph, Guelph, ON) from July 1 to September 9,2002. The animals were housed in the main barn at the EDRC until approximately $7 \mathrm{~d}$ prior to each SARA week (d 29 to 35) when they were moved into the Physiology Wing and put into individual tie stalls fully equipped for metabolism studies and for continuous measurement of ruminal $\mathrm{pH}$.

\section{Experimental Treatments and Feeding}

Experimental treatments were a monensin premix (Rumensin Premix, Elanco Animal Health, Division Eli Lilly Canada Inc., Guelph, ON, Canada) or a placebo premix. For the monensin premix, monensin was incorporated into soybean hulls, which acted as the carrier.
Table 1. Ingredients and chemical composition of the total mixed rations fed to lactating dairy cows.

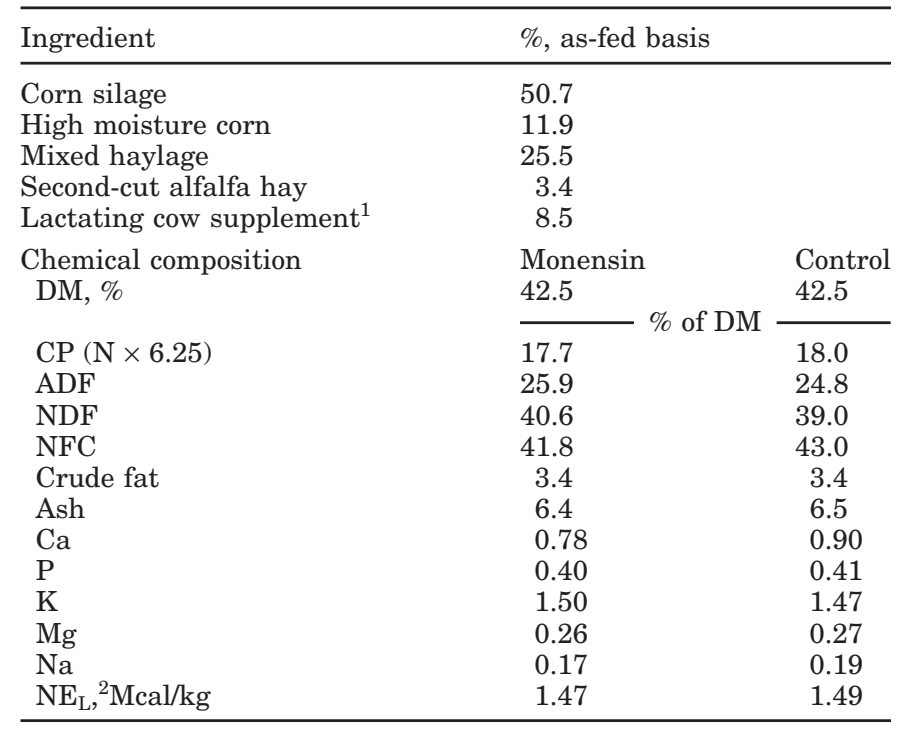

${ }^{1}$ Contained (DM basis): $41.0 \% \mathrm{CP}, 43.2 \%$ rumen undegradable protein $(\%$ of $\mathrm{CP}), 56.8 \%$ rumen degradable protein (\% of $\mathrm{CP}), 3.07 \% \mathrm{Ca}$, $1.23 \% \mathrm{P}, 0.62 \% \mathrm{Mg}, 1.25 \% \mathrm{~K}, 0.74 \% \mathrm{~S}, 1.04 \% \mathrm{Na}, 1.56 \% \mathrm{Cl}, 660 \mathrm{mg}$ of $\mathrm{Fe} / \mathrm{kg}, 496 \mathrm{mg}$ of $\mathrm{Zn} / \mathrm{kg}, 124 \mathrm{mg}$ of CU/kg, $495 \mathrm{mg}$ of Mn/kg, 1.27 $\mathrm{mg}$ of Se/kg, $8.4 \mathrm{mg}$ of $\mathrm{Co} / \mathrm{kg}, 5.72 \mathrm{mg}$ of I/kg, 52,890 IU of vitamin $\mathrm{A} / \mathrm{kg}, 13,230 \mathrm{IU}$ of vitamin $\mathrm{D} / \mathrm{kg}, 190 \mathrm{IU}$ vitamin $\mathrm{E} / \mathrm{kg}$.

${ }^{2}$ Estimated using equations and values according to NRC (1989).

The placebo (control) premix consisted of soybean hulls. The monensin premix was mixed with the TMR daily to achieve a rate of $22 \mathrm{mg}$ of monensin/ $\mathrm{kg}$ of TMR (DM basis). The placebo premix was mixed with TMR at the same rate as the monensin premix. Dietary composition and chemical analysis are shown in Table 1. Animals were fed TMR at 0700 and $1500 \mathrm{~h}$ for ad libitum consumption. For the initial $7 \mathrm{~d}$ of each experimental period, cows received unmedicated TMR (no monensin). Cows were then introduced to dietary treatments, with a 3 -wk adaptation period (d 8 to 28 ) and a 7-d measurement period (d 29 to 35). During the measurements period, individual cow feed intake was recorded daily. Feed (TMR) samples and orts were collected daily, stored at $-20^{\circ} \mathrm{C}$, and composited weekly. Pooled TMR and orts samples were analyzed for DM by drying in an oven at $60^{\circ} \mathrm{C}$ for $48 \mathrm{~h}(\mathrm{AOAC}, 1990)$, ADF (AOAC, 1990), NDF (Goering and Van Soest, 1970), and CP using the macro-Kjeldahl procedure (AOAC, 1990). Experimental cows were milked twice daily at 0500 and $1500 \mathrm{~h}$, and milk weights were recorded. Milk samples were collected daily from morning and afternoon milkings and preserved with 2-bromo-2nitropropane-1-2diol. Milk samples were then pooled daily based on milk yield, and pooled samples were immediately submitted to the Central Milk Testing Laboratory (Laboratory Services Division, University of Guelph, Guelph, ON) 
for compositional analysis. Milk samples were analyzed for $\mathrm{CP}$, fat, and lactose using a near-infrared analyzer (Foss System 4000, Foss Electric, Hillerd, Denmark) according to AOAC (1990).

\section{Induction of SARA and Continuous Measurement of Ruminal pH}

During wk 5 (d 29 to 35) of each experimental period, SARA was induced in all cows on a daily basis using a grain challenge experimental model that was developed by Keunen et al. (2002). This experimental model consisted of restricting TMR intake to $85 \%$ of ad libitum intake (as determined in the preceding 7-d period) and substituting with $15 \%$ grain pellets consisting of $50 \%$ wheat and $50 \%$ barley. The feeding schedule during SARA induction was as follows: 1) At $0700 \mathrm{~h}$, cows were fed $2 \mathrm{~kg}$ of the TMR; 2) At $0900 \mathrm{~h}$, cows were fed 2/3 of their daily grain pellet allowance; 3) At $1100 \mathrm{~h}$, cows were offered TMR for $30 \mathrm{~min}$; 4) At $1300 \mathrm{~h}$, cows were fed the remaining $1 / 3$ of their daily grain pellet allowance; 5) At $1500 \mathrm{~h}$, cows were offered TMR for $30 \mathrm{~min}$; 6) At $1700 \mathrm{~h}$, cows were fed the remainder of the daily allowance of TMR. Any grain pellets not consumed within 30 min of feeding were directly introduced into the rumen via the rumen cannulae. During the SARA period, ruminal $\mathrm{pH}$ was recorded on a continuous basis using indwelling $\mathrm{pH}$ probes as described by Cumby et al. (2001). Briefly, a pH probe was suspended in the ventral sac of the rumen through a rumen cannula and linked directly to a computer. A $\mathrm{pH}$ reading was taken every second, averaged over every $60 \mathrm{~s}$, and then stored. The $\mathrm{pH}$ probes and $\mathrm{pH}$ transmitters were calibrated with pH 4 and 7 buffer solutions (Fisher Scientific, Fairlawn, NJ) twice per week (i.e., on d 29 and 33), and the position of the $\mathrm{pH}$ probes in the rumen was checked daily for each cow. The continuous ruminal $\mathrm{pH}$ data were summarized for each 24 -h period by calculating the mean $\mathrm{pH}$, the amount of time below $\mathrm{pH} 6.0$ and 5.6, and the area (time $\times \mathrm{pH}$ ) below $\mathrm{pH} 6.0$ and 5.6.

Fecal $\mathrm{pH}$ during SARA was monitored. Fecal rectal grab samples were collected on d 34 at 4-h intervals between 0900 and $2100 \mathrm{~h}$. Fecal samples $(80 \mathrm{~g})$ were combined with distilled water $(40 \mathrm{~g})$ in cups, then sealed and shaken by hand to make the feces an even consistency. Measurements of $\mathrm{pH}$ were taken immediately using a Corning Benchtop pH meter (Corning 220, Corning Inc., Corning NY) and an Accumet Gel-filtered Polymet Body Combination Electrode (Fisher Scientific) calibrated with $\mathrm{pH} 4.0$ and 7.0 buffer solutions (Fisher Scientific).

\section{Ruminal Forage Degradability and Total Tract Diet Digestibility}

Ruminal forage degradability and total tract diet digestibility were measured during the SARA week (d 29 to 35) of each experimental period. Ruminal forage degradability was determined using the in situ (nylon bag) technique (Ørskov et al., 1980), and test feeds were corn silage and alfalfa haylage. After oven drying at $60^{\circ} \mathrm{C}$ and grinding through a 1-mm screen (Thomas Wiley, Philadelphia, PA), test feeds were weighed (5$\mathrm{g}$ sample) into nylon bags. Starting on d 31 of each experimental period, duplicate nylon bags containing test feeds were incubated in the rumen of each cow for $3,6,12,24,48$, and $72 \mathrm{~h}$. After each incubation time, duplicate bags of each test feed were withdrawn from the rumen and hand-washed in lukewarm water for 5 min. Nylon bags containing test feed residues were then oven-dried for $48 \mathrm{~h}$ at $60^{\circ} \mathrm{C}$, and DM loss was determined. Dried feed residues were then analyzed for NDF (Goering and Van Soest, 1970). To determine DM losses during bag washing, 3 nylon bags (5-g sample) of each test feed (nonincubated) were hand-washed in lukewarm water for $5 \mathrm{~min}$ and then oven-dried for $48 \mathrm{~h}$ at $60^{\circ} \mathrm{C}$. Ruminal DM and NDF degradabilities were fitted to an exponential equation using the SAS nonlinear regression procedure (SAS, 1990). Parameters that were calculated were: A, washing loss; B, potential degradability after washing; $(\mathrm{A}+\mathrm{B})$, potential total degradability; and c, degradability rate constant (Ørskov et al., 1980).

Total tract diet digestibility was determined using the total collection technique (Plaizier et al., 2000). Between d 29 and 35, representative TMR samples were obtained daily and stored frozen at $-20^{\circ} \mathrm{C}$ until later analysis. Urine was collected using indwelling bladder catheters (Bardex Foley catheter, 75-mL capacity balloon; C. R. Bard Inc., Covington, GA) as described by Wright et al. (1998) to avoid feces contamination, and was discarded on a daily basis. All feces were collected in large steel trays positioned over the gutter behind each cow. On a daily basis at approximately $1100 \mathrm{~h}$, all feces were removed from the trays and placed in large plastic tubs. Feces were weighed and thoroughly mixed, and subsamples (approximately $1 \mathrm{~kg}$ ) were taken and stored frozen at $-20^{\circ} \mathrm{C}$. Before chemical analysis, frozen fecal samples were thawed and oven-dried for $48 \mathrm{~h}$ at $60^{\circ} \mathrm{C}$. After drying, samples were pulverized, and pooled by weight (using oven DM values) for each cow and period. After drying again, the pooled samples were ground through a 3-mm screen on the Retsch SM 2000 (Denmark) and then ground through a 1-mm screen on the Retsch ZM 100 (Denmark). Pooled samples of feeds, orts, and feces were analyzed for CP using the macro- 
Table 2. Ruminal $\mathrm{pH}$ characteristics and fecal $\mathrm{pH}$ during subacute ruminal acidosis (SARA) in lactating Holstein dairy cows as affected by supplementation with a monensin premix.

\begin{tabular}{lcccc}
\hline Item & Monensin & Control & SE & $P$ value \\
\hline Ruminal pH characteristics & & & & \\
Mean pH & 6.11 & 6.07 & 0.05 & 0.57 \\
Minimum pH & 5.39 & 5.27 & 0.13 & 0.58 \\
Maximum pH & 6.77 & 6.79 & 0.08 & 0.87 \\
Minutes pH < 6, min/d & 566.3 & 591.4 & 39.8 & 0.69 \\
Area $\mathrm{pH}<6, \mathrm{~min} \mathrm{pH} / \mathrm{d}$ & 199.6 & 276.8 & 46.0 & 0.32 \\
Minutes pH <5.6, min/d & 198.1 & 301.5 & 66.6 & 0.36 \\
Area $\mathrm{pH}<5.6, \mathrm{~min} \mathrm{pH} / \mathrm{d}$ & 53.9 & 100.5 & 29.3 & 0.35 \\
Fecal pH & 6.46 & 6.34 & 0.07 & 0.31 \\
\hline
\end{tabular}

Kjeldahl procedure (AOAC, 1990), ADF (AOAC, 1990), NDF (Goering and Van Soest, 1970), crude fat (AOAC, 1990), ash (AOAC, 1990), and gross energy using a C5000 calorimeter (IKA Analysetechnik, Heitersheim, Germany).

\section{Statistical Analysis}

The ANOVA was conducted using the SAS general linear models procedure (SAS, 1990) using the following general model:

$$
\mathrm{Y}_{\mathrm{ijk}}=\mu+\alpha_{\mathrm{i}}+\beta_{\mathrm{j}}+\tau_{\mathrm{k}}+\varepsilon_{\mathrm{ijk}}
$$

where

$$
\begin{aligned}
\mathrm{Y}_{\mathrm{ijk}} & =\text { the dependent variable, } \\
\mu & =\text { overall mean, } \\
\alpha_{\mathrm{i}} & =\text { effect of cow }(\mathrm{i}=1,2,3,4,5,6), \\
\beta_{\mathrm{j}} & =\text { effect of period }(\mathrm{j}=1,2), \\
\tau_{\mathrm{k}} & =\text { effect of treatment }(\mathrm{k}=1,2), \text { and } \\
\varepsilon_{\mathrm{ijk}} & =\text { random residual error. }
\end{aligned}
$$

For dependent variables that had repeated measurements (ruminal $\mathrm{pH}$ ), the repeated measurement option within the SAS (1990) GLM procedure was used. Effects were considered significant at a probability $P<0.05$, unless otherwise indicated.

\section{RESULTS AND DISCUSSION}

\section{SARA and Ruminal Forage Degradability and Total Tract Diet Digestibility}

Data on ruminal $\mathrm{pH}$ characteristics during SARA are presented in Table 2 . The minimum amount of time per day that ruminal $\mathrm{pH}$ was below $6(\geq 9 \mathrm{~h})$ and 5.6 $(\geq 3 \mathrm{~h}$ ), and minimum ruminal $\mathrm{pH}$ values of 5.27 to 5.39 (Table 2) that were observed for both control and monensin-treated cows during the grain challenge indicate that cows experienced prolonged periods of low ruminal $\mathrm{pH}$ that are indicative of SARA. This is consis- tent with the findings of other researchers (see Keunen et al., 2002; Mutsvangwa et al, 2002) who used a similar grain challenge model to induce SARA. Mean ruminal $\mathrm{pH}$, amount of time per day that $\mathrm{pH}$ was below 6 and 5.6 , and the area (time $\times \mathrm{pH}$ ) that $\mathrm{pH}$ was below 6 and 5.6 were not different $(P>0.05)$ between control and monensin-treated cows during SARA (Table 2). This is in agreement with a previous study from our laboratory (Mutsvangwa et al., 2002), indicating that monensin was not efficacious in increasing ruminal $\mathrm{pH}$ under the SARA conditions used in this study. Supplementation with monensin had no effect $(P>0.05)$ on mean fecal $\mathrm{pH}$ during SARA (Table 2), and this is consistent with the lack of effect of monensin on ruminal $\mathrm{pH}$.

Other studies (Green et al., 1999) have reported that monensin increased ruminal $\mathrm{pH}$ in periparturient dairy cows. Monensin increases ruminal $\mathrm{pH}$ primarily by inhibiting lactate-producing bacteria, which would otherwise proliferate in abundant starchy conditions. This reduction in ruminal lactate concentration, which is the major "driver" of acidosis when high grain diets are fed, raises ruminal $\mathrm{pH}$ (Russell and Hino, 1985; Callaway and Martin, 1997). In feedlot experiments in which monensin was potent in preventing extreme drops in ruminal $\mathrm{pH}$ following consumption of readily fermentable carbohydrates, ruminal lactate concentrations were generally high, exceeding $5 \mathrm{~m} M$ (Owens et al., 1998). We did not measure ruminal lactate concentrations in the present study; however, in the nutritional model employed in this study to induce SARA, ruminal lactate concentration does not exceed $1 \mathrm{~m} M$ (Plaizier et al., unpublished data), and this level is much lower than the threshold of $5 \mathrm{~m} M$ above which monensin has been reported to increase ruminal $\mathrm{pH}$ (Owens et al., 1998; Oetzel et al., 1999). For this reason, we can surmise that SARA in our experimental cows was not lactateinduced, and ruminal $\mathrm{pH}$ declined primarily as a function of VFA concentrations and, therefore, the inhibitory effect of monensin on lactate production would have played only a minor role in the regulation of ruminal $\mathrm{pH}$ in the current study. 
Table 3. Ruminal degradability of DM and NDF for corn silage and haylage during subacute ruminal acidosis (SARA) in lactating Holstein dairy cows as affected by supplementation with a monensin premix.

\begin{tabular}{|c|c|c|c|c|}
\hline Item & Monensin & Control & $\mathrm{SE}$ & $P$ Value \\
\hline \multicolumn{5}{|l|}{ DM degradability } \\
\hline \multicolumn{5}{|l|}{ Corn silage } \\
\hline $\mathrm{A}+\mathrm{B},{ }^{1} \%$ & 80.9 & 83.7 & 3.0 & 0.56 \\
\hline $\mathrm{B},{ }^{2} \%$ & 30.7 & 34.7 & 4.3 & 0.56 \\
\hline $\mathrm{c},{ }^{3} \% \mathrm{~h}^{-1}$ & 2.1 & 2.4 & 0.2 & 0.40 \\
\hline 24-h degradability, \% & 61.0 & 63.1 & 0.9 & 0.21 \\
\hline 48-h degradability, $\%$ & 69.0 & 73.0 & 2.0 & 0.27 \\
\hline \multicolumn{5}{|l|}{ Haylage } \\
\hline $\mathrm{A}+\mathrm{B}, \%$ & 72.4 & 71.8 & 0.6 & 0.53 \\
\hline $\mathrm{B}, \%$ & 39.6 & 38.7 & 1.0 & 0.59 \\
\hline c, $\% \mathrm{~h}^{-1}$ & 3.3 & 3.8 & 0.3 & 0.39 \\
\hline 24-h degradability, \% & 53.7 & 56.2 & 1.9 & 0.43 \\
\hline 48-h degradability, \% & 66.1 & 68.7 & 2.3 & 0.48 \\
\hline \multicolumn{5}{|l|}{ NDF degradability } \\
\hline \multicolumn{5}{|l|}{ Corn silage } \\
\hline $\mathrm{A}+\mathrm{B}, \%$ & 49.6 & 54.2 & 3.5 & 0.42 \\
\hline $\mathrm{B}, \%$ & 43.7 & 47.2 & 3.9 & 0.58 \\
\hline c, $\% \mathrm{~h}^{-1}$ & 2.2 & 2.3 & 0.1 & 0.50 \\
\hline 24-h degradability, \% & 16.7 & 21.3 & 1.9 & 0.20 \\
\hline 48-h degradability, $\%$ & 33.5 & 42.3 & 5.2 & 0.32 \\
\hline \multicolumn{5}{|l|}{ Haylage } \\
\hline $\mathrm{A}+\mathrm{B}, \%$ & 59.2 & 60.8 & 0.4 & 0.07 \\
\hline $\mathrm{B}, \%$ & 49.3 & 49.5 & 0.5 & 0.77 \\
\hline $\mathrm{c}, \% \mathrm{~h}^{-1}$ & 3.2 & 3.3 & 0.3 & 0.85 \\
\hline 24-h degradability, $\%$ & 33.9 & 36.9 & 2.5 & 0.46 \\
\hline 48-h degradability, $\%$ & 51.5 & 55.3 & 4.1 & 0.56 \\
\hline
\end{tabular}

${ }^{1} \mathrm{~A}+\mathrm{B}=$ Potential degradability; $\mathrm{A}=$ washing losses.

${ }^{2} \mathrm{~B}=$ Potential degradability minus washing loss.

${ }^{3} \mathrm{c}=$ Degradation rate constant.

The primary objective of this study was to determine the effects of monensin supplementation during graininduced SARA on ruminal forage degradability and total tract diet digestibility. Several in vivo studies have investigated the effects of monensin supplementation (Muntifering et al., 1981; Haïmoud et al., 1995; Plaizier et al., 2000) or grain-induced SARA (Krajcarski-Hunt et al., 2002; Plaizier et al., 2002) on ruminal forage degradability or total tract digestibility; however, to our knowledge, this is the first study to investigate the effects of monensin supplementation during grain-induced SARA on ruminal forage degradability and total tract digestibility. In the present study, monensin supplementation did not affect $(P>0.05) 24$ - or 48 -h ruminal DM and NDF disappearance when haylage or corn silage was incubated in the rumen during SARA (Table 3 ). Because monensin has been reported to attenuate SARA in both beef cattle (Nagaraja et al., 1985; Cooper and Klopfenstein, 1996) and dairy cattle (Green et al., 1999), we anticipated that dietary supplementation with monensin in dairy cows subjected to SARA would make the ruminal environment more favorable for the proliferation of cellulolytic bacteria by increasing ruminal $\mathrm{pH}$, thereby reducing the characteristic decrease in fiber digestion that has been observed during SARA (Krajcarski-Hunt et al., 2002; Plaizier et al., 2002).
Somewhat surprisingly, ruminal fiber digestion was unaffected by the addition of monensin (Table 3). All indicators of SARA that we measured in the present study, including mean ruminal $\mathrm{pH}$, minimum ruminal $\mathrm{pH}$, and duration of time when ruminal $\mathrm{pH}<6$ and $<5.6$, were not different between control and monensintreated cows (see Table 2), suggesting that monensin was ineffective in attenuating SARA. In addition, average ruminal $\mathrm{pH}$ during SARA, i.e., 6.07 and 6.11 for control and monensin-treated cows, respectively, indicate that only a mild ruminal acidosis might have been induced, likely driven by higher ruminal VFA concentrations, rather than higher ruminal lactate concentrations. Ruminal fiber digestion is depressed when ruminal pH declines below 6.2 (Grant and Mertens, 1992), and the average ruminal $\mathrm{pH}$ values observed in the present study for both control and monensin-treated cows were fairly close to this threshold ruminal $\mathrm{pH}$. It is plausible, therefore, that ruminal $\mathrm{pH}$ conditions might not have been detrimental to fiber digestion in the present study. For these reasons, any potential benefits of monensin supplementation on ruminal fiber digestion might be expected to be small.

In the present experiment, cows were under conditions of experimentally induced SARA (albeit mild) and, for that reason, any direct comparisons of the effects of 
Table 4. Total tract apparent diet digestibilities during subacute ruminal acidosis in Holstein dairy cows as affected by supplementation with a monensin premix.

\begin{tabular}{lllll}
\hline Item & Monensin & Control & SE & $P$ Value \\
\hline Apparent digestibility, \% & & & & \\
DM & 65.5 & 62.2 & 1.4 & 0.19 \\
CP & 66.0 & 62.8 & 1.3 & 0.19 \\
NDF & 54.8 & 45.8 & 2.6 & 0.09 \\
ADF & 51.4 & 44.1 & 1.7 & 0.05 \\
Crude fat & 78.0 & 75.9 & 2.7 & 0.62 \\
Ash & 37.9 & 33.5 & 2.2 & 0.26 \\
NFC & 75.7 & 76.8 & 1.3 & 0.59 \\
GE & 65.4 & 61.6 & 1.2 & 0.10 \\
\hline
\end{tabular}

monensin on diet digestion with published studies in which monensin was supplemented under "normal" feeding conditions might be somewhat misleading. However, the average ruminal $\mathrm{pH}$ observed in the present study was $>6$, similar to average ruminal $\mathrm{pH}$ of 6 observed for control and monensin-treated cows in the study by Haïmond et al. (1995), so direct comparisons with the present study are valid. In contrast with results from our study, Haïmond et al. (1995) observed that monensin supplementation altered dietary nutrient digestion by decreasing ruminal fiber digestion; however, postruminal (small intestinal) fiber digestion was higher with monensin supplementation, such that total tract fiber digestion was not changed. Monensin, therefore, shifted the site of fiber digestion from the rumen to postruminal sites. In the present study, monensin did not affect ruminal fiber digestion (Table 3), but it increased $(P=0.05)$ total tract $\mathrm{ADF}$ digestion and tended to increase $(P=0.09)$ total tract NDF digestion (Table 4). We did not measure small intestinal fiber digestion in the present study, but we can surmise from our results that dietary addition of monensin increased postruminal fiber digestion, thereby increasing total tract fiber digestion even though ruminal fiber digestion was unaffected. Perusal of the literature indicates that the influence of monensin on ruminal or postruminal nutrient digestion has not been consistent. Monensin supplementation reduced ruminal nutrient digestion in some studies with cattle or sheep fed concentrate or forage diets (Owens et al., 1978; Simpson, 1980; Muntifering et al., 1981), but not in others (Morris et al., 1990; Rogers et al., 1991). Reasons for these discrepancies between studies may include differences in dietary inclusion levels of monensin, and interactions between feed intake and composition, and monensin (Mutsvangwa et al., 2002). Total tract digestion of DM, CP, crude fat, ash, nonfiber carbohydrates, and gross energy were unaffected $(P>0.05)$ by the dietary addition of monensin (Table 4).

\section{Feed Intake and Milk Production}

Monensin supplementation did not affect $(P>0.05)$ DMI and milk yield under experimentally induced SARA conditions (Table 5). Considerable research has been devoted to determining the effects of monensin on DMI and milk yield in dairy cows. A preponderance of data indicate that the well-documented effects of adding monensin to dairy cow diets have been increased milk production in conjunction with no change or a decrease in DMI (van der Werf et al., 1998; Phipps et al., 2000; Ruiz et al., 2001), thereby suggesting that monensin improved the efficiency of feed utilization. However, in the current study dairy cows were under conditions of experimentally induced SARA and direct comparisons with published studies in which monensin was supplemented under "normal" feeding conditions would be somewhat misleading. In previous research

Table 5. Dry matter intake, and milk production and composition of Holstein dairy cows during subacute ruminal acidosis (SARA) as affected by supplementation with a monensin premix.

\begin{tabular}{lccll}
\hline Item & Monensin & Control & SE & $P$ Value \\
\hline DMI, kg/d & 17.5 & 16.9 & 1.3 & 0.77 \\
Milk yield, kg/d & 25.6 & 25.2 & 1.2 & 0.84 \\
Fat, \% & 3.26 & 3.78 & 0.25 & 0.24 \\
Protein, \% & 3.09 & 3.32 & 0.06 & 0.09 \\
Lactose, \% & 4.61 & 4.60 & 0.10 & 0.96 \\
Fat, kg/d & 0.82 & 0.94 & 0.06 & 0.23 \\
Protein, kg/d & 0.78 & 0.82 & 0.05 & 0.62 \\
Lactose, kg/d & 1.19 & 1.16 & 0.08 & 0.79 \\
\hline
\end{tabular}


from our laboratory in which SARA was induced by feeding additional grain (see Mutsvangwa et al., 2002), we observed that cows fed a monensin premix ate more $\mathrm{DM}(+1.5$ to $+2.8 \mathrm{~kg} / \mathrm{d})$ and, consequently, produced more milk $(+3.6$ to $+4.0 \mathrm{~kg} / \mathrm{d})$ compared with control cows. Reasons for discrepancies between that previous study and the present study are unclear but could be related to differences in stage of lactation between the 2 studies. However, the lack of response in DMI and milk production due to monensin supplementation that we observed in the present study is in agreement with earlier trials (Lean et al., 1994; Hayes et al., 1996; Green et al., 1999; Vallimont et al. 2001).

Treatment with monensin had no effect $(P>0.05)$ on milk content of fat and protein, and milk fat and protein yields (Table 5). However, milk fat content in monensintreated cows was 0.52 percentage units lower than control cows (Table 5). The magnitude of the decrease in milk fat content due to monensin supplementation was higher than that reported to be significant in other studies (e.g., 0.26 to 0.32 percentage units reported by Mutsvangwa et al., 2002). Differences in milk fat content in the present study were not significant, likely because standard errors were larger compared with the study of Mutsvangwa et al. (2002), i.e., 0.25 vs. 0.04 to 0.06 . However, the observed trends in decreasing milk fat content due to the administration of monensin have been reported in other studies (van der Werf et al., 1998; Phipps et al., 2000; Vallimont et al., 2001). Milk contents and yields of protein were unaffected $(P>0.05)$ by dietary supplementation with monensin (Table 6), and this is in agreement with other studies (van der Werf et al., 1998; Green et al., 1999; Ruiz et al., 2001; Mutsvangwa et al., 2002).

\section{CONCLUSIONS}

In summary, monensin premix supplementation had no effect on ruminal $\mathrm{pH}$ characteristics, indicating that monensin was not efficacious in attenuating SARA. In addition, adding monensin to the diet did not affect ruminal fiber digestion during SARA, likely because only a mild ruminal acidosis was induced and, therefore, ruminal $\mathrm{pH}$ conditions might not have been detrimental to fiber digestion. However, total tract fiber digestion was increased by adding monensin to the diet, suggesting that monensin supplementation increased fiber digestion at postruminal sites. These results suggest that monensin might be a potential tool for improving nutrient digestion during grain-induced SARA in dairy cows.

\section{ACKNOWLEDGMENTS}

The authors would like to thank Angela Fairfield and the staff of the Elora Dairy Research Centre (University of Guelph, ON, Canada) for their technical assistance, and Elanco Animal Health, Division Eli Lilly Canada Inc. (Guelph, ON, Canada) for their financial support. We would also like to acknowledge the continued support received from the Ontario Ministry of Agriculture and Food (OMAF) and the Natural Sciences and Engineering Council of Canada (BWM).

\section{REFERENCES}

Association of Official Analytical Chemists. 1990. Official Methods of Analysis. 15th ed. AOAC, Arlington, VA.

Burrin, D. G., and R. A. Britton. 1986. Response to monensin in cattle during subacute acidosis. J. Anim. Sci. 63:888-893.

Callaway, T. R., and S. A. Martin. 1997. Effects of cellobiose and monensin on in vitro fermentation of organic acids by mixed ruminal bacteria. J. Dairy Sci. 80:1126-1135.

Calsamiglia, S., A. Ferret, and M. Devant. 2002. Effects of $\mathrm{pH}$ and $\mathrm{pH}$ fluctuations on microbial fermentation and nutrient flow from a dual-flow continuous culture system. J. Dairy Sci. 85:574-579.

Cooper, R., and T. J. Klopfenstein. 1996. Effect of Rumensin and feed intake variation on ruminal pH. Pages A1-A14 in Scientific Update on Rumensin/Tylan/Micotil for the Professional Feedlot Consultant. Elanco Animal Health, Indianapolis, IN.

Cumby, J. L., J. C. Plaizier, I. Kyriazakis, and B. W. McBride. 2001. Effect of subacute ruminal acidosis on the preference of cows for pellets containing sodium bicarbonate. Can. J. Anim. Sci. 81:149-152.

Dennis, S. M., T. G. Nagaraja, and E. E. Bartley. 1981. Effects of lasalocid or monensin on lactate producing or using rumen bacteria. J. Anim. Sci. 52:418.

Goering, H. K., and P. J. Van Soest. 1970. Forage fiber analyses (apparatus, reagents, procedures, and some applications), Agric. Handbook No. 379. ARS-USDA, Washington, DC.

Grant, R. J., and D. R. Mertens. 1992. Influence of buffer $\mathrm{pH}$ and raw corn starch addition on in vitro fiber digestion kinetics. J. Dairy Sci. 75:2762-2768.

Green, B. L., B. W. McBride, W. D. Sandals, K. E. Leslie, R. Bagg, and P. Dick. 1999. The impact of the monensin controlled release capsule upon subclinical acidosis in the transition dairy cow. J. Dairy Sci. 82:333-342.

Haïmoud, D. A., M. Vernay, C. Bayourthe, and R. Moncoulon. 1995. Avoparcin and monensin effects on the digestion of nutrients in dairy cows fed a mixed diet. Can J. Anim. Sci. 75:379-385.

Hayes, D. P., D. U. Pfeiffer, and N. B. Williamson. 1996. Effect of intraruminal capsules on reproductive performance and milk production of dairy cows fed pasture. J. Dairy Sci. 79:1000-1008.

Keunen, J. E., J. C. Plaizier, I. Kyriazkis, T. F. Duffield, T. M. Widowski, M. I. Lindinger, and B. W. McBride. 2002. Effects of subacute ruminal acidosis model on the diet selection of dairy cows. J. Dairy Sci. 85:3304-3313.

3313. Krajcarski-Hunt, H., J. C. Plaizier, J. P. Walton, R. Spratt, and B. W. McBride. 2002. Effect of subacute ruminal acidosis on in situ fiber digestion in lactating dairy cows. J. Dairy Sci. 85:570-573.

Lean, I. J., M. Curtis, R. Dyson, and B. Lowe. 1994. Effects of sodium monensin on reproductive performance of dairy cattle. Effects on conception rates, calving to conception intervals, calving to heat and milk production in dairy cows. Aust. Vet. J. 71:273-277.

McGuffey, R. K., L. F. Richardson, and J. D. Wilkinson. 2001. Ionophores for dairy cattle: current status and future outlook. J. Dairy Sci. 84(Suppl.):E194-E203.

Morris, F. E., M. E. Branine, M. L. Galyean, M. E. Hubbert, A. S. Freeman, and G. P. Lofgreen. 1990. Effects of rotating monensin plus tylosin and lasalocid on performance, ruminal fermentation, and site and extent of digestion in feedlot cattle. J. Anim. Sci. 68:3069-3078. 
Muntifering, R. B., B. Theurer, and T. H. Noon. 1981. Effects of monensin on site and extent of whole corn digestion and bacterial protein synthesis in beef steers. J. Anim. Sci. 53:1565-1573.

Mutsvangwa, T., J. P. Walton, J. C. Plaizier, T. F. Duffield, R. Bagg, P. Dick, G. Vessie, and B. W. McBride. 2002. Effects of a monensin controlled-release capsule or premix on attenuation of subacute ruminal acidosis in dairy cows. J. Dairy Sci. 85:3454-3502.

Nagaraja, T. G., T. B. Avery, S. J. Galitzert, and D. L. Holman. 1985. Effect of ionophore antibiotics on experimentally induced lactic acidosis in cattle. Am. J. Vet. Res. 46:2444-2452.

National Research Council. 2001. Nutrient Requirements of Dairy Cattle. 7th rev. ed. National Acad. Sci., Washington, DC.

Nocek, J. E. 1997. Bovine acidosis: Implications on laminitis. J. Dairy Sci. 80:1005-1028.

NRC. 1989. National Research Council. Nutrient Requirements of Dairy Cattle. 6th Rev. Ed. National Academy Press, Washington, DC.

Oetzel, R. R., K. V. Nordlund, and E. F. Garret. 1999. Effect of ruminal $\mathrm{pH}$ and stage of lactation on ruminal lactate concentration in dairy cows. J. Dairy Sci. 82(Suppl. 1):38. (Abstr.)

Ørskov, E. R., F. D. D. Hovell, and F. Mould. 1980. The use of the nylon bag technique for the evaluation of feed stuffs. Trop. Anim. Prod. 5:195-213.

Owens, F. N., B. Shockey, R. W. Fent, and S. R. Rust. 1978. Monensin and abomasal protein passage of steers. J. Anim. Sci. 47(Suppl. 1):114. (Abstr.)

Owens, F. N., D. S. Secrist, W. J. Hill, and D. R. Gill. 1998. Acidosis in cattle: A review. J. Anim. Sci. 76:275-286.

Phipps, R. H., J. I. D. Wilkinson, L. J. Jonker, M. Tarrant, A. K. Jones, and A. Hodge. 2000. Effect of monensin on milk production of Holstein-Friesian dairy cows. J. Dairy Sci. 83:2789-2794.

Plaizier, J. C., A. Martin, T. F. Duffield, R. Bagg, P. Dick, and B. W. McBride. 2000. Effect of a prepartum administration of monensin in a controlled-release capsule on apparent digestibilities and nitrogen utilization in transition dairy cows. J. Dairy Sci. 83:2918-2925.

Plaizier, J. C., J. E. Keunen, J. P. Walton, T. F. Duffield, and B. W. McBride. 2001. Effect of subacute ruminal acidosis on in situ digestion of mixed hay in lactating dairy cows. Can. J. Anim. Sci. 81:421-423.

Rogers, M., J. P. Jouany, P. Thivend, and J. P. Fontenot. 1991. Comparative effects of feeding and duodenal infusion of monensin on digestion in sheep. Can. J. Anim. Sci. 71:1125-1133.

Ruiz, R., G. L. Albrecht, L. O. Tedeschi, G. Jarvis, J. B. Russell, and D. G. Fox. 2001. Effect of monensin on the performance and nitrogen utilization of lactating dairy cows consuming fresh forage. J. Dairy Sci. 84:1717-1727.

Russell, J. B., and T. Hino. 1985. Regulation of lactate production in Streptococcus bovis: A spiraling effect that contributes to rumen acidosis. J. Dairy Sci. 68:1712-1721.

SAS User's Guide. Statistics. Version 6 Edition. 1990. SAS Inst., Inc., Cary, NC.

Simpson, M. E. 1980. Effects of certain antibiotics on in vitro cellulose digestibility and volatile fatty acid production by ruminal microorganisms. J. Anim. Sci. 47 (Suppl. 1):429. (Abstr.)

Vallimont, J. E., G. A. Varga, A. Arieli, T. W. Cassidy, and K. A. Cummins. 2001. Effects of prepartum somatotropin and monensin on metabolism and production of periparturient Holstein dairy cows. J. Dairy Sci. 84:2607-2621.

Van der Werf, J. H. J, L. J. Jonker, and J. K. Oldenbroek. 1998 Effect of monensin on milk production by Holstein and Jersey cows. J. Dairy Sci. 81:427-433.

Wright, T. C., S. Moscardini, P. H. Luimes, P. Susmel, and B. W. McBride. 1998. Effects of rumen-undegradable protein and feed intake on nitrogen balance and milk protein production in dairy cows. J. Dairy Sci. 81:784-793. 